\title{
O CONTO DE FORMAÇÃO COMO SUBGÊNERO AUTOFICCIONAL EM KATHERINE MANSFIELD E CLARICE LISPECTOR
}

Edson Ribeiro da Silva

Resumo: O presente estudo focaliza a possibilidade do conto de formação como subgênero, tomando como paradigmas os contos "A casa de bonecas", de Katherine Mansfield, e "Felicidade clandestina", de Clarice Lispector. Esses contos são observados como obras autoficcionais, por se inserirem em um gênero ficcional, mas evidenciarem sua natureza autobiográfica. A noção de Bildung aparece neles e, de modo geral, no subgênero como crise que resulta em aprendizado. Teóricos como Lejeune, Searle, Doubrovsky, Alberca, Klinger e Puga servem como base para os conceitos que evidenciam a natureza formadora e autoficcional desses contos.

Palavras-chave: Autoficção. Conto de formação. Lispector. Mansfield.

Abstract: The present essay focuses on the possibility of the coming of age short-story as a subgenre, taking as a paradigm the short stories "The Doll's House", by Katherine Mansfield, and "Felicidade clandestina", by Clarice Lispector. These short stories are seen as selffictional works, since they are inserted in a fictional genre, but show their autobiographical nature. The notion of Bildung appears in the stories and, generally, in the subgenre as crisis that results in learning. Theorists such as Lejeune, Searle, Doubrovsky, Alberca, Klinger,and Puga serve as the basis for the concepts that demonstrate the formative and self-fictional nature of these short stories.

Keywords: Self-fiction. Coming of age short story. Lispector. Mansfield.

\section{O CONTO DE FORMAÇÃO COMO SUBGÊNERO}

No âmbito da teoria literária, é recorrente que se tenha a fluidez dos gêneros como um recurso que dispensa o pesquisador de explicitar procedimentos estéticos. 0 
conceito de gênero literário acaba sofrendo com a aplicação dessa fluidez a ele próprio. Essa pressa em não se especificar o que torna um autor ou uma obra um caso de estranhamento e de ruptura faz com que, tantas vezes, as possibilidades de invenção, as múltiplas estéticas sejam chamadas de gêneros.

Torna-se comum que o mesmo estudioso que chama o realismo fantástico de gênero use o mesmo conceito para definir obras que se insiram nessa estética, como contos ou romances. A autobiografia tem confundidas, tantas vezes, sua natureza como gênero literário ou como possibilidade de arranjo da linguagem literária em gêneros como o conto, o romance, a novela, a crônica, entre outros. O mesmo ocorre com a autoficção. É chamada de gênero até mesmo em estudos que focalizam obras como autoficcionais e pertencentes a estéticas específicas, como o realismo sociológico ou a prosa psicológica, também chamadas de gêneros sem o serem.

Esses equívocos acabam por contornar abordagens que interessam para a teoria literária, para a compreensão de procedimentos estéticos complexos e de autores marcados pelo estranhamento como capacidade de reelaborar os elementos que compõem a linguagem literária.

Da mesma forma que se encontra um uso disseminado de aplicações do conceito de gênero, como se não houvesse 
um marco especificável para o que caracteriza um gênero e o que faz de seus derivados subgêneros ou modalidades literários, existe uma resistência em se enxergarem aquelas semelhanças que tornam problemáticas ou ainda insuficientes as abordagens de certas escolhas artísticas.

Um exemplo notório é o modo como o conto, como gênero literário estabelecido, "cristalizado", como diria Bakhtin (1992, p. 277), ainda sofre com abordagens que focalizam casos relevantes dentro de épocas ou para a própria evolução do que se reconhece como tal, mas que ainda ficam receosas diante da possibilidade de aplicação de terminologias utilizadas no estudo do romance para a compreensão de procedimentos que também o explicam. Novamente, é recorrente que o conto não seja abordado através de conceitos que a ele se aplicam, como o de autoficção ou o de metaficção historiográfica. Existe o Bildungsroman, o romance de formação, estudado a partir de diversas possibilidades; no entanto, as possibilidades de se focalizarem o conto de formação são mais restritas. Dizer que determinado autor produzia contos de formação ainda é atitude pouco notada, mesmo diante de casos em que a semelhança com o que é definido como formação nos estudos sobre o romance é elemento a partir do 
qual procedimentos artísticos atualmente indispensáveis foram construídos.

Portanto, quando se toma como modelo do que pode ser conceituado como conto de formação obras de Katherine Mansfield e de Clarice Lispector, evidenciam-se modos de o gênero conto assimilar estéticas que passaram por uma lenta progressão: a possibilidade de a formação ou daquilo que a exemplifica não dependerem de relatos extensos ou que seguem uma cronologia mais convencional. A autora neozelandesa e a brasileira possuem uma proximidade facilmente detectável, apontada pela própria Clarice mais de uma vez. Interessa, para o presente estudo, uma dessas possibilidades de aproximação: a autoficcionalidade de contos nos quais as duas autoras fazem uso da memória de episódios significativos da infância, que elas reconhecem como momentos de aprendizagem. O uso da memória como suporte para a ficcionalização do real é recorrente nas duas e ensejou modos diversos de experimentar com a linguagem literária.

Enxerga-se como autoficção, no presente estudo, aquela modalidade literária que se constitui, ou se configura, a partir do "pacto ambíguo", conforme o conceito com que Manuel Alberca (2007) destrava os 
limites estabelecidos por Doubrovsky e possibilita que a autoficcionalidade possa ser enxergada em inúmeras configurações literárias. Nessa direção, as duas autoras produzem contos autoficcionais quando fazem uso desse pacto de leitura, mesmo quando narram em terceira pessoa ou não nomeiam seus protagonistas.

Os contos que o presente estudo aborda são autoficcionais pela ambiguidade do pacto. $O$ fato de serem contos, gênero visto como ficcional por sua configuração, antes que pela natureza daquilo que é representado, já os estabelece dentro de um pacto que concede ao autor a possibilidade de reconfigurar a memória sem as exigências de comprovação do pacto autobiográfico, conforme Philippe Lejeune (2014), ou do texto documental, conforme John R. Searle (2002). A possibilidade de se reconhecerem tais contos como autobiográficos depende de elementos já profundamente abordados pelas teorias acerca da ficcionalidade, sobretudo o conceito de performance, estabelecido por Diana Klinger (2012). E as autoras, ainda que de modo menos enfático que aquele usado por autores de autoficção dos dias atuais, são performáticas ao se fazerem reconhecer em suas protagonistas.

A atenção recai, aqui, sobre os contos "A casa de bonecas", de Katherine Mansfield, e "Felicidade clandestina", de Clarice 
Lispector. É fato que existem diversos estudos em que esses mesmos contos são abordados. A existência de comparações entre os dois contos evidencia que as semelhanças entre ambos têm sido apreendidas a partir de mais de uma possibilidade. Mas a que sobressai, quando se buscam textos que tenham tais contos ou tais autoras como objeto, é a preocupação com a descoberta, pelas protagonistas crianças, das diferenças socioeconômicas geradoras de frustração e exclusão. Os procedimentos narrativos, como evidenciação da possibilidade de um gênero curto tratar da formação de seu protagonista, mesmo optando por enredos simples e pela duração curta das ações, constituindo a vertente do conto correspondente ao que o Bildungsroman, como subgênero, representa para o romance, parecem ainda não despertar o mesmo interesse de alguns que os comparam.

Os elementos aqui observados tornam-se uma sequência de ideias que interessa ao que se pretende demonstrar ao compararem-se dois contos de escritoras próximas pelos procedimentos artísticos, mas distanciadas quanto à possibilidade de uma escrita ficcional de teor autobiográfico poder ser reconhecida pelo leitor e ter alterado seu pacto de leitura. O leitor-ideal de ambas é aquele que leu sua escrita ensaística ou sua escrita-de-si, como diário, carta ou 
crônica. No caso de Clarice Lispector, até mesmo aquele que sabe que Katherine Mansfield era vista pela brasileira como uma autora assemelhada. A atitude performática altera-se conforme as possibilidades de um autor fazer-se reconhecível pela sua biografia ou personalidade. Se essa atitude, de alguma forma, atinge o ato da leitura, ela influencia os modos de recepção do texto. Assim, um conto pode ser assumido como autoficcional, que exibe um momento de formação da personalidade de seu autor.

\section{O CONTO DE FORMAÇÃO COMO SUBGÊNERO E SUA RELAÇÃO COM A MEMÓRIA}

Obras essenciais tratam o modo como a memória é elemento constitutivo da ficção, para autores abrangentes, como Roman Ingarden, Paul Ricoeur e Wolfgang Iser. É preciso focalizar-se, aqui, a necessidade de se perceberem modos como a memória pode ser usada para tratar da formação de uma subjetividade. Afinal, Lejeune associa a autobiografia à formação: "DEFINIÇÃO: narrativa retrospectiva em prosa que uma pessoa real faz de sua própria existência, quando focaliza especialmente sua história individual, em particular a história de sua personalidade" (LEJEUNE, 2008, p. 14). A formação da personalidade, como subjetividade, é indissociável da figura do herói problemático da narrativa 
de ficção. Se, na autobiografia, conforme Lejeune, o que se persegue, de fato, é a história da constituição de um sujeito notório, cuja vida é objeto de distinção, sobretudo no momento da narração, na ficção, essa história referese à formação de uma subjetividade problemática que procura representar a pessoa comum. A infância torna-se um momento privilegiado para se falar do autor que, no presente da narração, pode já ser figura notória.

O Bildungsroman representa uma possibilidade de representação da história de uma personalidade, sua formação, mesmo sendo a de sujeitos comuns. Trata-se de uma possibilidade de romance em que a duração temporal é decisiva para que exista mudança na personagem, como aprendizado. A formação de uma personalidade exige que o eu sobre o qual se narra seja marcado pela mudança; a personalidade, de que fala Lejeune, só passa a ter sentido, na narrativa ficcional de formação, se ela for vista como condição daquele que narra quando está narrando ou como estado final da personagem, que pode então ser vista como causalidade para finais trágicos, de fracasso e, às vezes, de sucesso. Por isso, Ricoeur problematiza a ideia de uma identidade que possa ser vista como a de um mesmo nesse subgênero:

O dilema desaparece se a identidade entendida no sentido de um mesmo (idem) 
for substituída pela identidade entendida no sentido de um si-mesmo (ipse); a diferença entre idem e ipse não é outra senão a diferença entre uma identidade substancial ou formal e a identidade narrativa. [...] Diferentemente da identidade abstrata do Mesmo, a identidade narrativa, constitutiva da ipseidade, pode incluir a mudança, a mutabilidade, na coesão de uma vida. (RICOEUR, 2010, p. 419)

Essa mesma relação problemática entre existir uma identidade no protagonista como mesmo ou um conjunto de mudanças que faz dele um si-mesmo é tratada por Rogério Miguel Puga em seu esforço por definir o Bildungsroman. Ao tratar das divergências quanto às definições dadas, Puga recorre a Frederick Amrine, que busca uma solução mais abrangente, ao afirmar que

se tomarmos a Bildung no seu sentido mais restrito e historicamente limitado, nenhuma obra será um Bildungsroman, nem mesmo Wilhelm Meisters Lehrjahre, mas se a entendermos no seu sentido mais lato, como desenvolvimento do protagonista, então todo o romance será um Bildungsroman, sendo, na nossa opinião, essa problemática clarificada se juntarmos ambos os critérios, em vez de os separar, ao definir o romance de formação tradicional como a representação do processo formativo informal do protagonista até ao início da sua 'vida adulta', momento em que acaba, normalmente 'em aberto', a acção do Bildungsroman. (PUGA, 2016, p. 11) 
Essa busca por uma categorização mais lata ainda esbarra na insistência em se ver, no protagonista, o adulto. Novamente, uma insistência que retiraria dessa categoria obras notoriamente definidas como tal, como Os Buddenbrooks, de Thomas Mann, em que o protagonista morre ainda na adolescência. Nesse romance, o narrador em terceira pessoa não pode ser identificado a nenhuma personagem. Puga menciona outras abordagens do subgênero, até chegar a algumas mais recentes, que atentam para modos diversos de a formação do protagonista ocorrer:

O Bildungsroman é assim definido a partir do seu conteúdo temático, e a sua principal característica é a primazia conferida quer à formação do protagonista a partir da interacção com o mundo, quer à interrelação entre as forças sociais e psicológicas que determinam a direcção do processo de auto-desenvolvimento ou pathos desse indivíduo. Essa relação entre o Self e a sociedade é revelada, não através do relato de toda a vida do protagonista, mas a partir de acontecimentos ou experiências iniciais que têm uma influência específica na sua formação [...]. (PUGA, 2016, p. 25)

Percebe-se que a extensão da narrativa, que abrange uma duração cronológica extensa, não é elemento imprescindível. Está-se, portanto, mais próximo daquilo que o século 20 fez do romance de formação: 
O Bildungsroman tradicional funciona frequentemente como um programa de identificação com a ordem social e com o sistema de valores da sociedade ao representar a assimilação dos códigos de conduta vigentes pelos protagonistas, enquanto, por exemplo, o Bildungsroman étnico ou pós-colonial se afasta do padrão tradicional para se ocupar do processo que leva o indivíduo a consciencializar-se da diferença/alteridade e a identificar-se com ou a rejeitar os modelos que a sociedade the oferece-impõe [...]. (PUGA, 2016, p. 18)

No trecho anteriormente citado, Puga evidencia a possibilidade de o romance de formação atentar para um único aspecto da constituição da personalidade da personagem. No trecho imediatamente acima, Puga focaliza a diferença entre aprendizado de condutas padronizadas e o aprendizado mais recorrente no herói problemático do romance de formação moderno, que é a atitude crítica diante de padrões estabelecidos.

A junção dos dois aspectos, redução da atenção a um elemento da formação da personagem e atitude conflitante em relação aos padrões que deveriam ser aprendidos, acaba por mostrar procedimentos que o conto tem adotado, sobretudo a partir do momento em que ele se assume como um gênero com especificidades que o distinguem da novela e do conto popular. As contribuições de autores como 
Poe, Maupassant e Tchékhov, para que o conto adquirisse uma autonomia em relação aos gêneros dos quais ele se originou, como as novelas do Decamerão ou de Cervantes ou os contos orais coletados pelos irmãos Grimm, acabam por fazer dele um modo de narrar que busca a invenção, o estranhamento, a inovação em detrimento da sedimentação. Ou seja, a relação entre o paradigma e a inovação torna-se contrato de leitura, como queria Ricoeur (1994, p. 118): “É ainda o ato de ler que acompanha o jogo entre a inovação e a sedimentação dos paradigmas que esquematizam a tessitura da intriga".

Se Poe desenvolveu a concentração da ação em poucas páginas, fazendo com que tudo no conto tivesse um único centro agregador, a ser evidenciado no final da narrativa, Maupassant é um autor voltado para a cena, sem tanta preocupação com tramas voltadas para o desfecho. Tchékhov, por sua vez, é reconhecido como o criador do conto de atmosfera: narrativas com baixa concentração de ações e a busca por um efeito passional sobre o leitor, obtido sobretudo por aquilo que as vozes dos narradores não dizem, mas que aquele precisa perceber. Para isso, Tchékhov elabora narrativas impressionistas, em que há um predomínio dos pontos de vista limitados das personagens 
em relação à visão totalizadora de narradores oniscientes tradicionais, para os quais o autor elabora um jogo de vozes, como as narrativas autodiegéticas intercaladas na voz do narrador objetivo, extradiegético, ou a inserção de cenas, em que a voz, concedida aos personagens, revela conflitos e personalidades que o narrador não descreve na sua voz.

Tchékhov valoriza o momento específico em que uma experiência é vivenciada e passa a constituir uma personalidade. O aprendizado é recorrente. No conto "Vanka", o menino, aprendiz em uma sapataria distante de sua cidade, afastado de seus familiares, escreve cartas para o avô. O fato de o menino estar perplexo diante da crueldade das pessoas que o cercam, mas de não a compreender, e de o narrador extradiegético não a explicar ao leitor, cria o efeito de empatia e a negação daquilo que a criança é obrigada a assimilar. O mesmo pode ser percebido nos diversos contos em que o autor russo, que atuou como médico em cidades de província, antes de se dedicar à literatura, usou como protagonista a figura do médico de província inserido em ambientes em que se torna o inadaptado, humilhado pelas pessoas de classes mais abastadas e de intensa vida mundana. O fato de essa personalidade ser recorrente em protagonistas do autor, 
assim como as situações que o jovem médico experimenta, aponta para uma intenção autobiográfica. Contos como "O beijo", "lônytch", "A irrequieta" e "A dama do cachorrinho" tratam do fracasso profissional e sentimental desse médico de província. Poderiam ser categorizados a partir daquilo que Lejeune define como ficção autobiográfica, em que um pacto de leitura pode deixar impreciso o teor autobiográfico, sem que se faça do reconhecimento dele uma exigência para o sucesso dela. O leitor-ideal contemporâneo de Tchékhov até pode reconhecer nesses contos uma ambiguidade autoficcional. Mas não se pode ver no autor russo aquela atitude performática de quem quer ser reconhecido na personagem ficcional.

Não se pode negar ao autor a preocupação com a formação da personalidade de certos protagonistas. 0 médico rural protagonista de "lônytch" cantarola, no início do conto: "Quando eu ainda não havia bebido da taça da vida" (TCHÉKHOV, 2014, p. 119). O fato de eles estarem, como Vanka, em situações de aprendizado formal, ou como o médico rural Ossip Stepânitch Dýmov, de "A irrequieta", em situações de aprendizado informal, faz com que essa condição do conto como obra de formação não precise de uma duração cronológica extensa: o aprendizado refere-se a 
aspectos específicos da vida, como a crueldade e a falsidade de pessoas próximas. O uso do biografema no conto de formação não está lá para que o autor se autoelogie ou proclame suas ideologias; a função da memória é garantir veracidade ao narrado ou é matéria de onde o enredo se origina. A representação do fracasso pessoal contribui para que se criem atmosferas de impacto passional. A personagem criança, tal como o menino protagonista de $A$ estepe, ou o menino Vanka, reforça a opção pela narrativa de formação. O elemento autobiográfico, através de informações paratextuais, é evidenciado na introdução que Rubens Figueiredo fez para a novela:

Seu desafio era escrever uma narrativa sem enredo, sem heróis, sem outra crise que não um resfriado que o menino legóruchka pega na viagem. Uma narrativa sem aventuras e ações de impacto, senão aquelas presentes, de forma indireta, nas histórias meio inventadas que os carroceiros da estepe contam para legóruchka. [...]

A fonte do texto foi uma viagem que Tchékhov fizera um ano antes a Taganrog, sua cidade natal, à beira do Mar Cáspio. A região que ele percorreu se parece bastante com a descrita na novela. Em cartas à irmã, naquela ocasião, encontramos referências a vários elementos presentes em $A$ estepe - a prisão, o cemitério, os mercadores, traços da fala das pessoas etc. E numa carta ao editor de Siéverni Viéstnik, Tchékhov afirma 
que as duas cruzes na beira da estrada citadas na novela existem de fato e que, aos dezessete anos, quando fez uma viagem, o jovem Tchékhov adoeceu numa estalagem e recebeu os cuidados de um judeu chamado Moissei Moisséievitch, que de fato aparece com esse nome em $A$ estepe. (FIGUEIREDO, 2015, p. 7)

O teor autobiográfico é comprovado pela recorrência a textos pessoais do escritor, como suas cartas. Para o leitor que recebe essa informação, antes da leitura da novela, a recepção da obra como ficcional sofre alterações no pacto: saber-se da natureza autobiográfica serve aqui como uma confirmação da prefiguração ou Mímesis I, de que tratava Paul Ricoeur (1994). Essa memória, como base para a elaboração da narrativa literária, é um dos três tipos de mímesis que originam a ficção: a prefiguração (Mímesis I), a configuração (Mímesis II), e a refiguração (Mímesis III). A primeira é a memória daquilo que o autor experienciou. Essa memória contém as imagens que formam qualquer narrativa. $\mathrm{O}$ universo que um autor representa em sua narrativa, mesmo que a queira recebida como produto do imaginário, é aquele contido na sua memória. A configuração, que é o momento em que se transforma em elaboração artística esses dados apanhados na memória, gera a obra a partir das intenções do autor. Em Ricoeur, essa intenção é transformada pela 
memória do leitor: a refiguração ocorre como leitura e nela a experiência pessoal de quem lê adapta a narrativa ao conjunto de imagens que formam o seu universo empírico. Não há, para o filósofo, nenhum problema que torne impraticável uma leitura eficiente.

A memória serve como base para que o escritor fale de uma experiência que, em princípio, pode parecer ausência de enredo. A "crise" como desencadeador da aprendizagem é elemento recorrente nas obras de aprendizado, assim como a viagem é parte de uma simbologia literária, que a atrela ao desenvolvimento de uma personalidade, à formação submetida ao devir. A crise serve como motivo, em uma novela, como $A$ estepe, que o próprio autor, conforme Rubens Figueiredo, na mesma introdução, disse parecer-se mais com um conto curto. Passar por uma crise significa beber um pouco da taça da vida, ou seja, aprender.

A ideia de que é possível a existência do subgênero conto de formação tem no autor russo um caso específico, pois nele a memória passa a ser evidente elemento que serve como base para a configuração ficcional; quanto à refiguração, essa depende da experiência daquele que lê, como leitorideal ou leitor comum, da possibilidade de acesso aos biografemas de que o autor faz uso. Mas a atenção para a 
formação, mesmo em contos como "Vanka", de teor menos autobiográfico (mas presente, para o leitor que atrela as condições de vida do autor durante sua educação formal às da personagem), faz do autor um dos formuladores desse subgênero. A atenção recai mais sobre o efeito das ações narradas sobre a personalidade da personagem que sobre elas em si mesmas. O conto acaba por fazer da contenção um modo de a formação ganhar em dramaticidade e de aparecer como inconclusa, imprecisa, característica acima atrelada ao romance de formação mais recente.

A Tchékhov é creditada a criação do conto de atmosfera, no sentido de narrativa menos preocupada com as peripécias que com a dramaticidade da crise e seu efeito sobre uma personagem. $\mathrm{O}$ conto de atmosfera é parte de uma tendência generalizada da literatura moderna de preocupar-se com a psicologia das personagens. A representação do ato de apreensão de real e das vozes que a corporificam para o leitor possibilita essa atenção para a produção do texto como contrato inicial de leitura, algo que fica evidente em $O$ ato da leitura, de Wolfgang Iser (1996), e seu conceito de leitorideal. O leitor pretendido pelo conto de atmosfera é aquele capaz de enxergar o modo como a crise, como fragmento, desencadeia tanto modos de apreensão do real como 
enseja o desenvolvimento de técnicas de representação que evidenciam o efeito da realidade sobre a psicologia dos personagens. A aprendizagem, como processo, pode ser um desses efeitos. Assim como o aprendizado, como resultado. Mais que uma formação que necessita de tempo para ocorrer, e que procura ter como resultado um narrador maduro ou um protagonista descrito como formado, o conto de formação, ou mesmo uma novela, como A estepe, ou "Campo geral", de João Guimarães Rosa, procura o efeito da desorientação psicológica do protagonista e a proximidade da experiência com sua narração. É uma razão pela qual é recorrente que um narrador em terceira pessoa fale por essas crianças, pois a utilização de suas vozes, configuradas como relato escrito, implicaria em resolver o efeito de desorientação. Esse narrador assume o ponto-de-vista das personagens em crise, no momento mesmo em que ela ocorre.

A possibilidade de a formação de uma personalidade ser representada como crise, mesmo que a ela não se dê uma solução duradoura, é significativa do que alguns teóricos apontam como a passagem do gênero tale para o short-story, palavras que em inglês evidenciam modos diferentes de configuração textual, que a palavra "conto", em português, por si só não contém. Afinal, por short-story pode-se entender 
o conto conforme emancipado de sua ligação com a tradição oral do tale, ou ainda como esse gênero superou as técnicas narrativas preocupadas com a representação do real para assumir as técnicas da modernidade que Luiz Costa Lima (1980) definiu como "mimesis da produção". Essas técnicas possibilitam que a narrativa curta assuma uma natureza de fragmento, de incompletude, que também é assumido pelos gêneros mais longos.

Esses exemplos levam à conclusão de que existe sim a possibilidade de outros gêneros narrativos, como o conto, assumirem a formação como temática e o consequente desenvolvimento de técnicas para representá-la, que resultaram em um subgênero, o conto de formação. Ao mesmo tempo, evidenciam que essa condição não pode estar restrita a especificidades do romance nem a eventos recorrentes em narrativas como as de filmes de amadurecimento. A maturidade alcançada pelo conto deu a ele a autonomia da experimentação e possibilidades de refiguração como estranhamento.

\section{"A CASA DE BONECAS" E "FELICIDADE CLANDESTINA" COMO CONTOS DE FORMAÇÃO}

A adoção do ponto-de-vista da criança, com uma consequente elaboração do discurso daquela, mesmo por 
um narrador adulto, constitui, sem dúvida, a marca distintiva de contistas como Clarice Lispector. O uso de uma falsa terceira pessoa é recorrente em autores que falam da própria infância, como ocorre em Infância e em Juventude, de J. M. Coetzee. O efeito é o da representação da fala da personagem, ou o modo como a linguagem representa sua apreensão da realidade, numa terceira pessoa que possa ser lembrada, depois da leitura, como tendo fingido ser uma primeira.

Clarice Lispector adotava procedimentos assim para seus protagonistas crianças. A modernidade da sua linguagem exige que seu leitor-ideal esteja de posse de tais estratégias. O mesmo ocorre com a modernidade de Katherine Mansfield. No caso desta, é preciso que se entenda a oscilação entre os discursos do narrador adulto e da personagem criança. Conceder a voz a determinada personagem, em momento de intensificação do efeito de passionalidade que se tenta obter, pode representar o instante em que o percurso de crise e aprendizado aponta para algum resultado.

Foram as leituras de Tchékhov que indicaram à jovem escritora Katherine Mansfield a possibilidade de fazer da narrativa curta o meio mais adequado de representação do 
real e de experimentação com modos modernos de narrar. A autora passa a demandar lembranças de fatos que contêm a crise para que, a partir do efeito dela sobre as personagens, configure as atmosferas também perseguidas por Tchékhov.

A memória, para a escritora neozelandesa, poderia representar um modo mais verídico de se pensar a configuração de uma narrativa. Mas antes de ser escolha, a memória existe como material de vida já elaborado, restando à autora transformá-la em arte. Como ela afirma em carta a sua amiga Ida Parker, figura identificável em algumas personagens ficcionais:

Obrigada pelo pano de cetim cinza com todos os seus pequenos caseados. Fizeramme sorrir. Meu estojo de escrever parece excessivamente suntuoso sobre ele. Lembrame a Ida que amo. Não por causa do quanto custou. Não. Mas por causa do "impulso" - do gesto - do que você chama a "coisa perfeita". Leva-me de volta a Isolla Bella. Oh, memória! Retorno a Casetta e ainda antes à oliveira e ao algodoeiro ao longo da cerca enredada, às rosas vermelhas e às grandes margaridas de olhos estrelados. Menton parece conter anos de vida. Como é difícil escapar dos lugares! Por mais cuidadosa que possamos ser, eles nos prendem - deixamos pequenos pedaços de nós mesmas ondulando sobre as cercas - pequenos farrapos e fiapos de nossa própria vida. Mas estranho é que - isto é pessoal - por mais penoso que algo possa ter sido, quando recordo não o é mais - ou 
não mais penoso que a música. Na verdade, é exatamente assim. Agora, quando ouço o mar em Casetta, é insuportavelmente belo. (MANSFIELD, 2020, s.p.)

Mansfield tratava-se de uma daquelas personalidades para quem a exposição exacerbada de episódios da vida pessoal poderia significar escândalo ou repúdio. Através de uma carta, ela pode focalizar tal aspecto. No entanto, sua ficção autobiográfica não se acovarda. A autora escreve ensaios, mantém uma correspondência intensa, escreve rotineiramente na imprensa, o que a torna facilmente reconhecível como autora de ficção autobiográfica para aquele conjunto mais reduzido que correspondia a seu leitores-ideais. Mansfield poderia ser considerada uma escritora performática apenas quando escrevia para aqueles que reconheceriam, em um ensaio seu, a relação direta da pessoa com algumas personagens. O conhecimento de biografemas da autora, como os nomes de suas irmãs, torna reconhecível a natureza autoficcional de alguns de seus principais contos. Mas era uma ambição que a autora deveria reduzir àquele leitor capaz de estabelecer um pacto ambíguo de leitura.

De Mansfiled, seu diário e suas cartas, publicados pela primeira vez em 1927, após a morte por tuberculose, aos 34 
anos, em 1923, funcionam como uma ancoragem de sua ficção na sua biografia. O diário íntimo, sobretudo, acaba por assumir para ela algumas das funções que Philippe Lejeune Ihe atribui, como a de aprendizado de si e a de reflexão sobre a própria produção literária, mas também aquela função primordial, que é a de fixação da memória. Nas palavras de Lejeune:

Mantemos um diário para fixar o tempo passado, que se esvanece atrás de nós, mas também por apreensão diante de nosso esvanecimento futuro. Mesmo secreto, a menos que se tenha coragem suficiente para destruí-lo, ou para mandar enterrálo consigo, o diário é apelo a uma leitura posterior: transmissão a algum alter ego perdido no futuro, ou modesta contribuição para a memória coletiva. Garrafa lançada ao mar. E também investimento: o valor de informação de um diário aumenta com o tempo. É como um seguro de vida que se alimenta tostão por tostão, dia após dia, com depósitos regulares. (LEJEUNE, 2014, p. 303)

Em Lejeune, essa memória parece um acúmulo, que forma uma linha condutora, uma história, mesmo que o autor do diário não pretenda, de imediato, construí-la. A pesquisadora chilena Muriel Alejandra Silva Vera, em sua tese El diário de vida como instrumento para la bildungsroman, aborda o modo como o diário assume a função de registro 
de formação, sobretudo para pessoas em crises ou passando por processos de aprendizado, que ela exemplifica com a adolescência. Para Vera, o diário serve como registro de formação de uma personalidade de modo tão evidente que ele acaba sendo usado como modelo narrativo em romances de formação. Como ela afirma:

El diario íntimo es un texto de carácter autobiográfico de un sujeto real que de forma espontánea registra su vida. Pertenece a los géneros referenciales, presenta rasgos de una obra no creativa y busca reflejar la vida privada del autor. [...] En breves palabras, el diario íntimo proporciona el perfil psicológico del autor-narrador sobre su perspectiva del entorno, de las circunstancias y de sus percepciones respecto a lo que acontece en su vida. (VERA, 2015, p. 27-28)

Vera se aproxima de Lejeune e de sua definição de autobiografia como narrativa que conta, do seu autor, "a história da formação de sua personalidade" (LEJEUNE, 2014, p. 16). O diário possui essa formação, conforme Lejeune afirma, mas sem que o fim dela represente, por definição, a conclusão do texto. "A autobiografia está virtualmente concluída desde o começo, uma vez que a narrativa que começamos deve terminar no momento em que escrevemos" (LEJEUNE, 2014, p. 314), enquanto "raros são os diários que contêm um fecho" (2014, p. 312), já que aqueles que possuem 
um fim são temáticos, como diários de viagem, de estudos, de doenças; contudo, aqueles voltados para a reflexão sobre si de modo indeterminado não chegam a uma conclusão. 0 diário como registro de uma formação indeterminada no tempo possibilita ao romance de formação um efeito de incompletude, quando este o mimetiza.

Quando se atenta para o fato de uma escritora ter mantido um diário que pode ser encontrado e publicado após sua morte, percebe-se a função dele como garrafa lançada ao mar. A fixação da memória da autora torna-se exposição desse passado. O leitor de diários ou de cartas, assim como o de biografias, reconhece o autor ou o assunto de tais textos. É certamente improvável que o leitor do gênero diário íntimo seja surpreendido pela sua temática. Provavelmente, ele é um leitor-ideal do autor. Aquele que percebe a relação entre a escrita-de-si e a ficção do autor. Katherine Mansfield torna-se, quando da publicação de seu diário, aquele autor performático de que fala Diana Klinger. A autora acrescenta, ao que já havia publicado além de sua ficção, um texto de natureza memorialística formativa não-ficcional. Mesmo à deriva, a mensagem na garrafa encontra um leitor-ideal, que reconhece como performance o lançamento daquela ao mar. A manutenção do que deve 
ser lido após sua morte é evidenciada pela autora em seu diário, em 1922: “Arrumei todos os meus papéis. Rasguei e destruí muitos inexoravelmente. Isso sempre me dá grande satisfação. Quando me preparo para uma viagem, é como se me preparasse para a morte. Se nunca voltar, está tudo em ordem. É o que a vida me ensinou" (MANSFIELD, 2020, s.p.).

O leitor de Clarice Lispector dispõe de uma extensa produção performática da escritora, sobretudo na forma de crônicas. A autora já escrevia como cronista antes da publicação de seu primeiro romance. O destaque recai sobre a sua produção para o Jornal do Brasil, entre os anos 60 e 70, época em que a inscrição do nome da escritora como já reconhecida pelo público possibilitava que, entre seus leitores, existissem leitores-ideais, capazes de reconhecerem o elemento performático naqueles textos próximos da escrita-de-si. Edgar Cézar Nolasco enxerga essas crônicas como "restos de ficção" (NOLASCO, 2004). Pode-se enxergar o elemento autobiográfico como um projeto de escrituração dela, material para a ficção, mas escancarado nessas suas escritas-de-si:

Podemos dizer que o traço biográfico é um leitmotiv, uma marca recorrente da construção da escrita literária de Clarice Lispector. Rastreando sua obra, constatamos que, desde seu livro de estréia, o traço biográfico já se fazia presente, arquiteturando 
seu futuro projeto literário. [...] Muitos de seus textos, por exemplo, vão ter como pano de fundo a memória da infância vivida, e de suas reminiscências sai a construção da sua ficção. (NOLASCO, 2004, p. 78-79)

O traço biográfico, nas obras de ficção, não é suficiente para que a autora construa a sua persona para aquele leitorideal que deve compartilhar a biografia da autora com elementos construídos para suas personagens, sobretudo as femininas. Existe uma encenação através da escrita:

Por outrolado, também podemos afirmar que Clarice tinha consciência dessa encenação do mundo da literatura, uma consciência tão peculiar como um jogo em que se ficcionaliza a própria vida. Por outro lado, o auto-retrato que vai criar para o outro, enquanto pessoa civil, acaba sendo parte de sua própria imagem ficcional, da "persona" literária construída no interior de sua escrita. É como se seu relato ficcional tivesse sido descolado de sua ficção para melhor representar e apresentar essa última para o leitor. Aqui, o pacto de leitura se propõe, então, enquanto desconstrução da estrutura de "verossimilhança" da "biografia" tradicional. (NOLASCO, 2004, p. 79)

A encenação é performance, sobretudo quando se tem em mente a produção de Clarice como escrita-de-si. Através de suas cartas, fica evidente a origem biográfica de sua produção ficcional. Através de suas crônicas, a autora pode expor essa condição para o seu leitor-ideal. A identidade 
entre o eu daquela que assina as crônicas com aquele que narra eventos ou tece comentários que falam de si assume uma condição performática, de formação de uma persona atrelável ao que se depreende de sua ficção. Fato notável é que a autora, após ter assumido uma coluna em jornal de grande circulação, pode fazer desse jogo, de que fala Nolasco, uma estratégia para elaboração de algumas de suas obras. Se a produção em conto da autora continuou reconhecível como tal, suas obras mais extensas, como Água viva, $A$ bela e a fera e Um sopro de vida passam a ser fluidas, não possuem gênero textual facilmente detectável. Água viva é exemplo notório desse compromisso da autora com a ambiguidade de gêneros. Tanto que o eu que narra evidencia a ambiguidade como intencionalidade e finge improvisar:

Inútil querer me classificar: eu simplesmente escapulo não deixando, gênero não me pega mais. (LISPECTOR, 1993, p. 17)

Sei o que estou fazendo aqui: estou improvisando. Mas que mal tem isso? Improviso como no jazz improvisam música, jazz em fúria, improviso diante da platéia. (LISPECTOR, 1993, p. 27)

Será que isto que estou te escrevendo é atrás do sentido? Raciocínio é que não é. (LISPECTOR, 1993, p. 37)

O improviso é a tônica do fingimento em Água viva. O livro, que já foi classificado como romance, ensaio, 
memórias, ficções, entre outros modos de as editoras tentarem explicar ao leitor o modo de recepção do texto sem a ambiguidade, foi composto a partir de diversas crônicas publicadas no Jornal do Brasil. De um conjunto de textos que ultrapassava duzentas páginas, a autora chegou às cerca de noventa páginas que integram a obra. As crônicas, já prontas, são agrupadas pela presença desse narrador em eu que produz literatura fingindo que o tempo da enunciação, ou da narração, é o único de que faz uso. O presente em que se narra ou se comenta é fingimento, mas torna possível ao leitor-ideal de Clarice reconhecer nesse narrador que diz eu aquelas características da persona criada por ela em suas crônicas:

Agora vou escrever ao correr da mão: não mexo no que ela escrever. Esse é um modo de não haver defasagem entre o instante e o eu: ajo no âmago do próprio instante. Mas de qualquer modo há alguma defasagem. (LISPECTOR, 1993, p. 58)

Para te escrever eu antes me perfumo toda. (LISPECTOR, 1993, p. 58)

Que estou fazendo ao te escrever? estou tentando fotografar o perfume.

Escrevo-te sentada junto de uma janela no alto de meu ateliê. (LISPECTOR, 1993, p. 59) Escrevo-te à medida do meu fôlego. Estarei sendo hermética como na minha pintura? Porque parece que se tem de ser terrivelmente explícita. Sou explícita? Pouco se me dá. Agora vou acender um 
cigarro. Talvez volte à maquina ou talvez pare por aqui mesmo para sempre. Eu, que nunca fui adequada.

Voltei. Estou pensando em tartarugas. Uma vez eu disse por pura intuição que a tartaruga era um animal dinossáurico. Depois é que vim ler que é mesmo. Tenho cada uma. Um dia vou pintar tartarugas. (LISPECTOR, 1993, p. 60)

O agora da narradora finge não haver defasagem de tempo. Trata-se de uma estratégia de estabelecimento de pacto de leitura. Ele é hermético, como a autora se define, retomando o discurso recorrente acerca de sua escrita. Um pacto hermético, ou ambíguo, em relação ao narrado, às condições estabelecidas sobre gênero. Mais que isso, àquelas condições sobre a natureza do texto, como autobiográfico ou como ficcional. Os elementos dispostos ao longo desse tempo da narração, o agora em que a autora finge improvisar um texto que, em sua grande maioria, já havia sido publicado como crônica, são de natureza paratópica, no sentido dado por Maingueneau (2012) em Discurso literário, ou seja, tratam daquele lugar onde o autor escreve, sobretudo aqueles que fizeram do ato de escrever um conjunto de rituais. Clarice indica, nos trechos acima, inúmeros elementos que constituem a sua cena enunciativa, ou seja, o ato de escrever, conforme ela 
própria já havia exposto em crônicas ou em entrevistas. Além dele, estão no trecho elementos como o hábito da pintura, o tabaco, escrever a máquina, fazê-lo sozinha. Demais elementos aparecem ao longo do livro, tornando a informação biográfica uma atitude performática.

Se Água viva ilustra uma dessas atitudes performáticas, elas também podem ser percebidas em obras posteriores, até mesmo na cenografia estabelecida para o narrador fictício de A hora da estrela, outra persona na qual o leitor deve reconhecer a autora. Esse reconhecimento refere-se ao modo de escrituração da própria Clarice Lispector. Os elementos de que ela faz uso evidenciam que sua produção ficcional, como seus contos, parte da memória. O atrelamento da memória à ficção torna a autora reconhecível em trechos como os seguintes, do conto "Tentação":

Ela estava com soluço. E como se não bastasse a claridade das duas horas, ela era ruiva. [...]

Lá vinha ele trotando, à frente de sua dona, arrastando seu comprimento. Desprevenido, acostumado, cachorro. [...)]

A menina abriu os olhos pasmada. No meio de tanta vaga impossibilidade e de tanto sol, ali estava a solução para a criança vermelha. E no meio de tantas ruas a serem trotadas, de tantos cães maiores, de tantos esgotos secos - lá estava uma menina, como se fora 
carne de sua ruiva carne. Eles se fitavam profundos, entregues, ausentes de Grajaú. Mais um instante e o suspenso sonho se quebraria, cedendo talvez à gravidade com que se pediam. (LISPECTOR, 1977, p. 59-60)

A cor do cabelo, no trecho, é um biografema. Assim como o gosto por cachorros. Da mesma forma, a presença da menina em um bairro do subúrbio do Rio de Janeiro, local que a autora conhecera durante sua infância. "Tentação" trata de um momento de epifania, instante fugidio, cena breve, mas onde existe a crise. Em outros contos, essa crise se prolonga e gera um aprendizado, seja pela superação ou pelo fracasso. A menina ruiva é recorrente em personagens que representam Clarice em obras ficcionais. Trata-se de um índice, com a intenção de que seja recebido como biografema pelo leitor. A cidade de Recife é outro local recorrente onde suas narrativas com personagens meninas acontecem, como em "Os desastres de Sofia" e "Felicidade clandestina". O fato de esses locais serem índices de identificação com a autora fica evidente na maneira como essas cidades não implicam em uma ambientação necessária às narrativas. Não há elementos que personalizem esses ambientes; eles são um efeito necessário ao aspecto autobiográfico e, para quem olha para elementos extratextuais, constituem um princípio de performance. 
No dia seguinte fui à sua casa, literalmente correndo. Ela não morava num sobrado como eu, e sim numa casa. Não me mandou entrar. Olhando bem para meus olhos, disse-me que havia emprestado o livro a outra menina, e que eu voltasse no dia seguinte para buscálo. Boquiaberta, saí devagar, mas em breve a esperança de novo me tomava toda e eu recomeçava na rua a andar pulando, que era o meu modo estranho de andar pelas ruas de Recife. (LISPECTOR, 1993, p. 7)

Trata-se de um procedimento narrativo recorrente em escritas de teor autobiográfico: o fato de serem dadas pistas ao leitor para que se reconheçam coincidências entre a ficção e a biografia. Outro elemento autobiográfico que assume essa condição é o objeto de desejo da menina protagonista. O gosto da menina Clarice Lispector pela leitura de Monteiro Lobato é biografema mencionado com insistência quando se fala da escritora, como se a literatura de tal autor tivesse sido um incentivo para a decisão de escrever. Em "Felicidade clandestina", o objeto de desejo é o livro Reinações de Narizinho. A personagem antagonista, colocada como exemplo de criança má, é motivo para a aprendizagem desencadeada pela crise. Uma garota má, reputada pelas meninas da escola como feia, deixada de lado nos momentos de interação espontânea, mas que é filha de dono de livraria. A sua maldade encontra no desejo da protagonista de ler 
aquele livro uma possibilidade de deleite e de vingança contra a sua condição de fora dos padrões aceitos pelas garotas. Assim, a protagonista passa dias indo à casa da garota má, que coloca desculpas para não lhe emprestar o livro. Até que a insistência em aparecer na casa da outra chama a atenção da mãe desta, que percebe o jogo maligno da filha e faz ela emprestar por tempo indeterminado o livro à protagonista.

A diferença entre aquele que possui e aquele que deseja e não pode comprar faz com que tal conto seja observado sob perspectivas sociológicas. Aqui, ele interessa como aplicação da memória ao que se reconhece como conto de formação. O que se aprende é a existência dessa maldade e a perda dessa incapacidade de identificar-se como vítima:

Mas que talento tinha para a crueldade. Ela toda era pura vingança, chupando balas com barulho. Como essa menina devia nos odiar, nós que éramos imperdoavelmente bonitinhas, esguias, altinhas, de cabelos livres. Comigo exerceu com calma ferocidade o seu sadismo. Na minha ânsia de ler, eu nem notava as humilhações a que ela me submetia: continuava a implorar-Ihe emprestados os livros que ela não lia.

Até que veio para ela o magno dia de começar a exercer sobre mim uma tortura chinesa. Como casualmente, informou-me que possuía As reinações de Narizinho, de Monteiro Lobato.

Era um livro grosso, meu Deus, era um livro para se ficar vivendo com ele, comendo-o, 
dormindo-o. E completamente acima de minhas posses. Disse-me que eu passasse pela sua casa no dia seguinte e que ela o emprestaria. (LISPECTOR, 1993, p. 7)

Não notar as humilhações é o estado inicial dessa menina em formação, em situação de aprendizado. O conto faz da escola o local onde as personagens se conhecem e onde passa a existir a crise, que vai levar a uma mudança: ser capaz de reconhecer a maldade, mas, sobretudo, de protelar o prazer como modo de torná-lo mais intenso. Por isso, a comparação que encerra o conto refere-se à condição de mulher e não de criança. Poder estar com seu amante, aguardando o momento do gozo, requer a paciência que a menina demonstrou para obter seu objeto de desejo. Talvez não seja coincidência que o romance de Clarice que trata do prazer na relação sexual como algo a ser aguardado, como uma Penélope que aguarda seu Ulisses, chame-se Uma aprendizagem ou o livro dos prazeres. O livro, como objeto de prazer, conduziu a menina em formação a algo semelhante a esse prazer. Trata-se de uma aprendizagem, projetada do livro para a possibilidade do amante:

Chegando em casa, não comecei a ler. Fingia que não o tinha, só para depois ter o susto de o ter. Horas depois abri-o, li algumas linhas maravilhosas, fechei-o de novo, fui passear pela casa, adiei ainda mais indo 
comer pão com manteiga, fingi que não sabia onde guardara o livro, achava-o, abria-o por alguns instantes. Criava as mais falsas dificuldades para aquela coisa clandestina que era a felicidade. A felicidade sempre iria ser clandestina para mim. Parece que eu já pressentia. Como demorei! Eu vivia no ar... Havia orgulho e pudor em mim. Eu era uma rainha delicada.

Às vezes sentava-me na rede, balançandome com o livro aberto no colo, sem tocá-lo, em êxtase puríssimo.

Não era mais uma menina com um livro: era uma mulher com o seu amante. (LISPECTOR, 1993, p. 9)

O amadurecimento remete também àquele sentimento que Katherine Mansfield coloca no conto "Felicidade", no original, "Bliss", palavra que levava Clarice a reivindicar "Êxtase" como nome mais adequado. Por isso, a menina do conto de Clarice sentia felicidade, mas depois de reconhecer que o sentimento era de verdadeiro "êxtase". É a voz de uma narradora adulta que reconhece a diferença entre os sentimentos; a personagem, em condição de aprendizagem, vive a sensação como epifania. Ter o livro em mãos significa a possibilidade de aprendizado da palavra, assim como do fazer literário.

A menina de Clarice Lispector, de notória inspiração autobiográfica, que a autora quer que seja percebida através 
de biografemas que seu leitor-ideal reconhece, passa por uma aprendizagem que envolve a diferença social. Desejar algo acima de suas posses, no caso, um livro, para alguém que faria da literatura um projeto de vida, representa chocarse contra uma barreira. A diferença social desencadeia uma crise quando o objeto de desejo precisa ser comprado.

A mesma situação ocorre no conto "A casa de bonecas", em que a aprendizagem tem no reconhecimento da diferença social o tema principal. Na verdade, o reconhecimento da impossibilidade de aquisição do objeto de desejo pelo outro. A protagonista de Katherine Mansfield exerce o papel da garota que possui esse objeto, por ser de família rica. Em vez de ser uma garota má, ela assume uma condição de menina esclarecida, uma exceção dentro de seu grupo, ao aprender que a privação de desejos pela qual passam as garotas pobres é algo injusto, sobre o qual se deve projetar alguma forma de luz. Do outro lado, as duas garotas pobres, que estudam também na mesma escola, a única do lugar, privadas do convívio com as mais abastadas nas relações informais e até mesmo nas atividades pedagógicas, e dos objetos de desejo que poderiam despertar a cobiça de meninas, ainda crianças, passam pelo aprendizado de sentirem a força da humilhação, a que serve como consolo 
o fato de terem visto o lampião colocado em um dos cômodos da casa de bonecas. O objeto exerce a função de propagador daquela luz que tanto as duas como a menina rica conseguem enxergar, mas as demais ainda não.

Katherine Mansfield escreveu cartas e fez registros em seu diário acerca desse conto. Ele é parte de uma trilogia que inclui "Prelúdio" e "Na baía" como anteriores. Os dois contos tinham sido elaborados, a princípio, como trechos de um romance, a ser chamado de Karori (nome do subúrbio para o qual se mudara em 1893 e que serve como cenário para vários de seus contos), no qual a autora pretendia não apenas tratar da sua infância e dos fatos que a marcaram e se tornaram desencadeadores de crise e de aprendizado, como a morte prematura do irmão caçula, mas também mostrar sua terra natal, a Nova Zelândia desconhecida da Europa colonizadora. São contos longos, divididos em trechos numerados. No primeiro deles, a atenção recai sobre o núcleo familiar. A estrutura fragmentada possibilita que a autora crie um ambiente doméstico, logo após a mudança da família para o que ela denomina "Baía de Crescent", o subúrbio de Karori, dedicando os fragmentos a pessoas diversas de seu convívio. Mansfield vale-se então de um índice recorrente na ficção de natureza autobiográfica que 
se quer reconhecida como tal: os nomes das personagens conservam certas semelhanças com os das pessoas que as inspiraram, como letras iniciais, terminações, sinônimos. A protagonista desses contos, Kezia, conserva a inicial da autora, enquanto uma irmã daquela é Lottie, diminutivo de Chartlotte, nome da segunda mais velha dentre as irmãs, dentre as quais Katherine, nascida Kathleen, era a caçula. Um dos nomes da família, Beauchamp, palavra em francês, aparece como Fairfield, palavra correspondente em inglês, para nome de uma personagem, em "Prelúdio". Esses índices ficam evidentes quanto a autora, nas suas escritas-de-si, fala desses contos. Como em uma carta de 1916:

Agora, agora quero escrever as recordações de meu país natal até que o estoque se acabe. Não apenas por ser uma "dívida sagrada" que saldo com meu país, por termos nascido lá, meu irmão e eu, mas também porque em meus pensamentos caminhamos os dois por todos aqueles lugares relembrados. Nunca me sinto longe deles. Desejo ardentemente recriá-los ao escrever. (MANSFIELD, 1996, p. 61)

O projeto de escrever um romance é levado a cabo durante anos, conforme se constata no trecho abaixo, de carta de 1921:

Acabo de terminar meu novo livro. Acabei-o na noite passada, às 10:30. Pousei a caneta 
depois de escrever "Graças a Deus". Eu gostaria que houvesse um Deus. Estou desejando 1) louvá-lo, 2) agradecer-lhe. O título é At the bay. Este é o nome de uma história muito longa que está nele uma continuação de Prelude. Tem cerca de sessenta páginas. Estive às voltas com ela na noite passada. Minhas preciosas crianças se sentaram ali, jogando cartas. Eu vaguei por todo tipo de lugares - entrando e saindo. Espero que seja bom. É tão bom quanto consigo fazer, e todo o meu coração e a minha alma estão nele... cada pedacinho deles. Oh Deus, espero que ele dê prazer a 60 alguém... É tão estranho trazer os mortos de novo à vida! Lá está minha avó, de volta à sua cadeira, com o tricô cor-de-rosa; meu tio caminha empertigado pela grama; sinto, enquanto escrevo, que "Vocês não estão mortos, meus queridos. Tudo é lembrado. $\mathrm{Eu}$ os reverencio. Eu me apago para que vocês possam viver novamente, através de mim, no seu valor e beleza". E a gente se sente possuída. $E$, além disso, o lugar onde tudo acontece. Tentei fazê-lo tão familiar a "vocês" como é para mim. (MANSFIELD, 2005, p. 232- 233)

No entanto, Mansfield abandona seu projeto, depois da recusa de um editor. Acrescenta ao que eram capítulos um terceiro conto, dessa vez breve e com um enredo mais linear: "A casa de bonecas" era a retomada de um conto escrito quando a autora tinha onze anos. No entanto, ele é composto a partir dos elementos que os dois anteriores já 
haviam estabelecido: um núcleo familiar e um cenário. Por isso, o conto se dedica a uma narrativa mais contida e com uma intensidade dramática mais acentuada. A trilogia sobre a família parece ter encontrado o fulcro que desestabiliza a ordem criada, aqui, no último conto. Se antes, havia encanto, agora este se reveste do peso da crise. O reconhecimento do outro, por Kezia, e a possibilidade de geração de uma crise, nas meninas pobres, sugerida pelo desfecho, encerram o que fora concebido como homenagem ao país e à família com uma mancha: a impossibilidade de posse do objeto de desejo pelos mais pobres, assim como a exclusão dos ambientes abastados, patrocinada pelos mais ricos.

Como conto de aprendizado, a crise de Kezia aparece no fato de ela atentar para o lampião, enquanto as demais irmãs parecem não o ter percebido:

Agora elas rondavam por fora; não se podia impedi-las de ouvir. Quando as meninas se viraram com desdém, Lil, como sempre, deu um sorriso desenxabido, acanhado, mas a nossa Else apenas ficou olhando.

E a voz de Isabel, cheia de orgulho, continuou contando. $O$ tapete provocou grande sensação, como também as camas, com roupa de cama de verdade, e o fogão, que tinha até a porta do forno.

Quando ela terminou, Kezia começou. "Você se esqueceu do lampião, Isabel."

"Ah, sim", disse Isabel, "e tem também um lampião bem pequeno, feito de vidro 
amarelo, com uma cúpula branca, em cima da mesa da sala de jantar. Parece um lampião de verdade".

"O lampião é o melhor de tudo", exclamou Kezia. Ela achou que Isabel não estava valorizando suficientemente o pequeno lampião. Mas ninguém prestou a mínima atenção. (MANSFIELD, 2005, p. 195)

A atenção para o lampião, como signo de iluminação e reconhecimento, ou seja, de aprendizado, faz de Kezia a menina que precisa aprender a desafiar o sistema em que vive, no qual as classes mais pobres são tratadas como exceção. As meninas Lil e Else, as Kelveys, são filhas de uma lavadeira. Na escola, até a professora as trata como exceções. E a mãe de Kezia a proíbe de levar as duas garotas para conhecer a casa de bonecas, depois de aquelas aceitas pela família terem já ido ver de perto o brinquedo que, desde que as meninas Burnells o tinham recebido como presente de uma conhecida, era o motivo das conversas informais na escola. Novamente, é na escola que as diferenças entre classes começam a interferir na vida extraescolar das meninas. Tal qual no Bildungsroman clássico, também já chamado de "romance de escola", o conto de formação recorre a esse espaço formal de aprendizagem para inserir a crise nas relações que acontecem fora dele. A aprendizagem informal de Kezia e das Kelveys encontra seu 
momento culminante no fato de as meninas pobres terem também prestado atenção no lampião:

Quando as Kelveys deixaram bem para trás a casa dos Burnells, sentaram-se para descansar em cima de um grande cano vermelho na beira da estrada. O rosto de Lil ainda queimava; ela tirou o chapéu e pousou-o sobre o joelho. As duas contemplaram sonhadoramente os campos de feno, o riacho, o curral, onde as vacas dos Logans esperavam para ser ordenhadas. 0 que elas estariam pensando?

Então a nossa Else aproximou-se e ficou bem junto de sua irmã. Mas agora já havia se esquecido daquela senhora brava. Esticou um dedo e deslizou-o pelo chapéu da irmã; sorriu seu raro sorriso.

"Eu vi a lampadinha", ela disse, suavemente. Então ficaram em silêncio outra vez. (MANSFIELD, 2005, p. 199)

Elas terem ficado em silêncio "outra vez" é um modo metanarrativo de a autora lembrar que apenas ali, ao final do conto, Ihes foi concedida a voz. O texto faz uso de uma terceira pessoa que, no caso, não quer expor um momento posterior das protagonistas, como adultas que já passaram pelo aprendizado possível, mas prefere focalizá-las como meninas que ainda não chegaram a uma conclusão sobre o que estão aprendendo. Se as duas meninas pobres vão voltar a ter voz, se elas estão iluminadas pela luz epifânica do lampião, é algo de que o leitor não vai saber as consequências. 
Para Kezia, fica o aprendizado de que a sociedade bem-vista e aceita em todos os contextos não enxerga com aprovação o seu gesto de incluir pessoas que deveriam permanecer fora e em silêncio:

"Como você se atreve a convidar estas meninas para vir ao quintal?", disse com frieza, furiosa. "Você sabe, tanto quanto eu, que não tem permissão de falar com elas. Vão embora, meninas, retirem-se. E não voltem mais", disse a tia Beryl. E andou até o quintal e, com um gesto brusco, espantou as meninas como se fossem galinhas.

"Saiam imediatamente!", disse, fria e orgulhosa. Elas não precisaram que lhes dissessem duas vezes. Vermelhas de vergonha, encolhidas, Lil com os braços cruzados no peito, num gesto humilde como sua mãe, a nossa Else, aturdida, atravessaram o grande quintal e esgueiraram-se pelo portão branco.

“Menina desobediente, má!", disse tia Beryl asperamente para Kezia, fechando com um gesto brusco a casa de bonecas. (MANSFIELD, 2005, p. 198-199)

Ser uma menina má, na visão de pessoas como a tia Beryl, parece ter constituído a subjetividade da moça e da adulta que Katherine Mansfield assumiu para si. A moça que, nas expressões elogiosas de hoje, estava "à frente de seu tempo", naquela época constituía um modelo de conduta que a sociedade rejeitava. A liberdade sexual ficava restrita a certos círculos, de artistas e intelectuais, quase sempre 
abastados. Mas era algo que se atrelava às meninas más, capazes da desobediência.

Mansfield assume aqui uma perspectiva em relação às diferenças sociais, presente no também autobiográfico, de natureza autoficcional, "A festa ao ar livre", em que uma menina rica leva uma cesta com alimentos a um operário acidentado, enquanto em sua casa as pessoas abastadas se divertiam numa festa. Quem vê fotografias do subúrbio de Karori, tiradas no começo do século passado, percebe um conjunto grande de casas que seguem o mesmo modelo, algumas alagadas por enchentes, enquanto a mansão da família Beauchamp se ergue senhorial e segura em um ponto elevado. Essa mansão com jardins, cercada por casas diminutas, constituiu um lugar para onde a escritora de hábitos arrojados não quis voltar, após sua mudança, no final da adolescência, para a Europa.

Como conto de aprendizagem, "A casa de bonecas" integra uma realização que remete àquele Tchékhov de contos como "Vanka". A relação entre a voz de um narrador ausente e a de certas personagens estabelece um jogo entre domínio do narrado e indeterminação. Vanka não sabe por que o maltratam no local de aprendizagem para onde o avô o enviou para morar. A escrita de uma carta é maneira de 
o menino expressar a incompletude de seu aprendizado: ele ainda não compreende a maldade humana nem as diferenças sociais. As meninas Kelveys pertencem a uma condição parecida, mas não semelhante, devido ao final otimista, apesar de patético, do conto. Ter visto o objeto de desejo mas não poder possuí-lo é elemento de crise a ser continuado indefinidamente. Não Ihes resta alternativa. Para a menina Kezia, a desobediência pode ser um modo de mostrar discordância.

Ali, onde Kezia é colocada em silêncio, como tantas personagens crianças, existe um princípio para a discordância através da escrita. Afinal, "A casa de bonecas" é a reutilização de um texto escrito quando Katherine Mansfield tinha onze anos. E "Felicidade clandestina" faz enxergar o conhecido episódio em que Clarice Lispector, aos 15 anos, ao receber o primeiro salário por textos publicados, comprou um livro de Mansfield e nela reconheceu a sua escrita. Como diz Nolasco:

Fica por conta da descoberta feita por Clarice do livro Felicidade o principal enredo da saga familiar de escritoras que vão marcar a escrita clariceana. É através da descoberta da escritora que a leitora Clarice vai descobrir o mundo da literatura (a livraria) como lugar onde gostaria de morar. É por conta ainda desse encontro que, mais tarde, traduz um trecho significativo de Mansfield 
e também julgamos vir daí o traço singular com que suas personagens literárias se relacionam com o livro, com a leitura. Esta primeira cena literária deve ficar restrita ao encontro literário, momento no qual a jovem leitora Clarice vive sua experiência extasiada diante da escrita não menos extasiada de Mansfield. (NOLASCO, 2004, p. 105-106)

Nolasco fala de uma escrita "extasiada", que retoma a sensação da menina com o livro de "Felicidade clandestina", daquela que pode assumir uma voz. De forma diferente, as Kelveys só puderam esboçar um sorriso com a lembrança do lampião. Assumir um discurso, fosse como escrita ou não, é algo que permanece de modo tênue, apenas um lampejo. Já Kezia pode, como disse Mansfield em uma das cartas citadas, apagar-se para que as outras possam viver. Por isso, seu aprendizado permanece como sugestão ao leitor. O seu leitor-ideal, tal como o de Clarice, sabe que as duas meninas aprendiam para que um dia pudessem representar esse aprendizado como autoras que falam de si mesmas. O conto de formação pode mostrar lampejos, em vez da luz ou das trevas definitivamente constituídas ambicionadas pelo Bildungsroman.

\section{CONSIDERAÇÕES FINAIS}

Mais que pela representação de diferenças sociais, os dois contos aqui observados, "A casa de bonecas" e "Felicidade 
clandestina", se assemelham por exemplificarem o que pode ser chamado de conto de formação. Trata-se, sem dúvida, de uma possibilidade que a escrita autobiográfica, através da assunção de identidades ficcionais, através de gêneros reconhecidos como tais pela intencionalidade que os gera, concede à narrativa literária. A fluidez de gêneros possibilita que as narrativas de formação assumam formatos mais experimentais que cristalizados. $O$ que pode ser considerado como formação é aquela característica de os textos tratarem de aprendizados.

O aprendizado, desde que o conceito passou a ser aplicado ao Bildungsroman, tem feito da personagem criança ou jovem o sujeito de uma crise que leva à aquisição de uma experiência da qual não se sai como antes. Se o romance de formação, pela extensão, pode chegar a aprendizados incontestáveis, o conto, pela brevidade, pode tratar da crise e de como as personagens se chocam com a realidade, sem que cheguem, essencialmente, a conclusões efetivas. Por isso, é talvez mais recorrente que se fale em epifania para tais momentos de aprendizado no conto que no romance.

A consumação do conto como um gênero com características próprias, que o afastavam das narrativas orais, fez com que ele assumisse a contenção, mas também 
a indeterminação. Por isso, o conto de atmosfera tornase mais propício para se tratar de instantes de crise que a narrativa de enredo concentrado, mas cheio de peripécias. Por isso, Tchékhov é mais modelar para o conto de formação que Poe.

Katherine Mansfield assume o aspecto desobediente de sua personagem Kezia. Além de uma biografia repleta de eventos considerados como desobediência a padrões morais, sua produção literária avança no sentido daquela modernidade que mostra ao receptor da obra a sua mímesis da produção. O leitor de Mansfield deve reconhecer, na sua produção, os recursos artísticos de que ela se vale. Para uma autora do começo do século 20 , seus contos podem ser focalizados, em princípio, como ficção autobiográfica, dada a exiguidade de recursos que possibilitassem que, através de atitudes performáticas, seu leitor contemporâneo reconhecesse, na sua ficção, os traços da sua biografia. No entanto, a autora deixou evidentes esses traços nas suas cartas, nos seus ensaios e no seu diário. Isso evidencia uma intencionalidade clara: ser apreendida como autora do que agora é definido como autoficção. Algo que se tornou possível, para o leitor-ideal por ela ambicionado, com a publicação desses textos de escritas-de-si. Mansfield 
deve ser apreendida como uma autora de autoficção naqueles textos em que ambiciona ser reconhecida nas suas personagens. O seu leitor-ideal deve estar de posse de seus biografemas e enxergar nessa escrita-de-si, mesmo a póstuma, uma reivindicação de performance.

No que se refere a Clarice Lispector, a autora contava com sua produção jornalística para que sua atitude performática pudesse levar seu leitor-ideal a receber sua ficção como autobiográfica, sem limites precisos, ou seja, através do pacto ambíguo que define a autoficção. $\mathrm{E}$, evidentemente, a publicação de outras escritas-de-si da autora, como cartas, após a sua morte, confirma essa condição. $\mathrm{O}$ fato de a autora exemplificar a migração de gêneros que ora são publicados como falando da autora, como suas crônicas, ora como romances ou obras indefinidas quanto ao gênero, exemplifica a autoficcionalidade em uma condição já exacerbada. A escrita de Clarice é autobiográfica por natureza.

Mansfield fez do conto a sua forma de expressão. Dentro dele, produziu contos de formação de natureza autoficcional. Clarice produziu contos, a parte mais canônica de sua produção, dentre eles contos de formação autoficcionais, enquanto suas obras mais extensas vão ganhando, ao longo dos anos, uma condição cada vez mais autobiográfica, que levou à indefinição de gêneros. 
Em ambos os casos, o elemento autobiográfico perseguiu a performance para se fazer reconhecido como tal. Assim como as semelhanças entre as autoras fazem com que o conto de formação tenha que ser reconhecido, também nelas, como um subgênero próprio dentro da literatura.

\section{REFERÊNCIAS}

ALBERCA, Manuel. El pacto ambiguo: de la novela autobiográfica a la autoficción. Madrid: Biblioteca Nueva, 2007.

BAKHTIN, Mikhail (1952-1953). Os gêneros do discurso. In: BAKHTIN, Mikhail. Estética da criação verbal. Tradução de Maria Ermantina Galvão Gomes e Pereira. São Paulo: Martins Fontes, 1992.

BAKHTIN, Mikhail. Questões de literatura e de estética (a teoria do romance). Tradução de Aurora Fornoni Bernardini et al. 6. ed. São Paulo: Editora Hucitec, 2010.

BAKHTIN, Mikhail. Teoria do romance I: a estilística. Tradução de Paulo Bezerra. São Paulo: Editora 34, 2015.

CARNEIRO, Sarah M. B. Clarice Lispector e Katherine Mansfield: relações de poder no universo infantil. 2013. Dissertação (Mestrado em Literatura Comparada) - Universidade Federal do Ceará, Fortaleza, 2013. DOUBROVSKY, Serge. O último eu. In: NORONHA, Jovita Maria Gerheim (Org.). Ensaios sobre a autofiç̧ão. Tradução de Jovita Maria Gerheim Noronha e Maria Inês Coimbra Guedes. Belo Horizonte: Editora UFMG, 2014.

FIGUEIREDO, Rubens. Introdução. In: TCHÉKHOV, Anton. A estepe (história de uma viagem). Tradução de Rubens Figueiredo. São Paulo: Companhia das Letras, 2015.

INGARDEN, Roman. A obra de arte literária. Tradução de Albin E. Beau, Maria da Conceição Puga e João F. Barrento. 3. ed. Lisboa: Fundação Celeste Gulbenkian, 1965. 
ISER, Wolfgang. $O$ ato de leitura: uma teoria do efeito estético. Vol. 1. Tradução de Johannes Kretschmer. São Paulo: Editora 34, 1996. KLINGER, Diana. Escritas de si, escritas do outro: o retorno do autor e a virada etnográfica. 3. ed. Rio de Janeiro: 7Letras, 2012.

LEJEUNE, Philippe. O pacto autobiográfico: de Rousseau à internet. Jovita Maria Gerheim Noronha (Org.). Tradução de Jovita Maria Gerheim Noronha e Maria Inês Coimbra Guedes. 2. ed. Belo Horizonte: Editora UFMG, 2014.

LIMA, Luiz C. Mímesis e modernidade: formas das sombras. Rio de Janeiro: Edições Graal, 1980.

LISPECTOR, Clarice. A legião estrangeira. São Paulo: Editora Ática, 1977. LISPECTOR, Clarice. Água viva. 12. ed. Rio de Janeiro: Francisco Alves, 1993. LISPECTOR, Clarice. Felicidade clandestina. Rio de Janeiro: Francisco Alves, 1993.

MATA, Anderson L. N. da. O silêncio das crianças: representação da infância na narrativa brasileira contemporânea. Londrina, PR: EDUEL, 2010.

MANSFIELD, Katherine. Diários e Cartas. Tradução de Julieta Cupertino. Rio de Janeiro: Revan, 1996.

MANSFIELD, Katherine. Contos. Tradução de Carlos Eugênio Marcondes de Moura e Alexandre Barbosa de Souza. São Paulo: Cosac \& Naify, 2005. MANSFIELD, Katherine. Algumas cartas e páginas do diário. Íbis: literaura \& arte. Disponível em: https://ibisliteraturaearte.com/revista/edicao 1/ algumas-cartas-e-paginas-do-diario/. Acesso em: 26 ago. 2020.

NOLASCO, Edgar C. Restos de ficção: a criação biográfico-literária de Clarice Lispector. São Paulo; Annablume Editora, 2004.

PUGA, Miguel Rogério. O bildungsroman (romance de formação): perspectivas. Lisboa: Centre for English, Translation and AngloPortuguese Studies (CETAPS); Faculdade de Ciências Sociais e Humanas - Universidade Nova de Lisboa, 2016.

RICOEUR. Paul. Tempo e narrativa. Vol. 3: O tempo narrado. Tradução de Claudia Berliner. São Paulo: WMF Martins Fontes, 2010. 
SARLO, Beatriz. Tempo passado: cultura da memória e guinada subjetiva. Tradução de Rosa Freire d’Aguiar. São Paulo: Companhia das Letras; Belo Horizonte: Editora UFMG, 2007.

SEARLE, John R. O estatuto lógico do discurso ficcional. In: SEARLE, John R. Expressão e significado: estudos da teoria dos atos de fala. Tradução de Ana Cecília G. A. de Camargo e Ana Luíza Marcondes Garcia. 2. ed. São Paulo: Martins Fontes, 2002.

TCHÉKHOV, Anton. A dama do cachorrinho e outras histórias. Tradução de Maria Aparecida Botelho Pereira Soares. Porto Alegre: L\&PM, 2014. VERA, Muriel A. S. El diário de vida como instrumento para la bildungsroman: dos casos: El caderno de Maya y El caderno de Mayra. Tese. Universidad de Santiago de Chile, Santiago, 2015.

VILELA, Luiz. Contos da infância e da adolescência. 2. ed. São Paulo: Editora Ática, 2001.

\section{Edson Ribeiro da Silva}

Pós-doutor em Letras (Estudos Literários) pela UEL.

Professor-titular da Uniandrade, Curitiba, Paraná. Professor do Programa de Mestrado e Doutorado em Teoria Literária.

E-mail: edribeiro@uol.com.br

Lattes: https://lattes.cnpq.br/4251342794401909

ORCID iD: http://orcid.org/0000-0003-1883-5893 